\title{
ACORDUL DE LA SCHENGEN. SITUATIA ROMÂNIEI
}

\author{
DOI:10.24193/SUBBiur.62(2017).3.6 \\ Published Online: 2017-09-30 \\ Published Print: 2017-09-30
}

Carmen LAZĂR*

Résumé. L'accord de Schengen. La situation de la Roumanie. A l'origine l'Accord de Schengen était un acte de droit international public, c'est-à-dire une convention conclue entre Etats membres qui complétait le droit communautaire parce qu'elle était destinée à atteindre l'objectif de la libre circulation fixé par les traités communautaires: ceux-ci permettaient seulement le déplacement en vertu d'un acte d'identité, tandis que l'Accord permet en plus le déplacement sans contrôles aux frontières entre les Etats parties. II illustre l'Europe à plusieurs vitesses, représente une forme de coopération consolidée, anticipant dans ce sens le Traité d'Amsterdam. L'Accord a été signé en 1985 par la France, l'Italie, la Belgique, le Luxembourg, les Pays-Bas et l'Allemagne, entré en vigueur d'une façon différenciée et complété par la Convention d'application de Schengen signée en 1990 et entrée en vigueur en 1995. D'autres Etats membres ont adheré à l'Accord et à la Convention, ce qui fait qu'actuellement sont parties presque tous les Etats membres de l'Union, moins la Grande Bretagne, I'Irlande et le Chypre (les deux premiers n'ont pas desiré être parties, mais participent quand même à certains aspects, le troisième a reçu une dérogation quand il a adhéré à l'Union), la Roumanie et la Bulgarie (qui ne remplissent pas toutes les conditions d'y participer). De même, par l'intermédiaire de conventions distinctes conclues entre eux et les Etats Schengen membres de l'Union, sont parties à l'Accord et à la Convention des Etats tiers comme l'Islande, la Norvège, le Liechtenstein et la Suisse. Par le Traité d'Amsterdam, signé en 1997 et entré en vigueur en 1999, l'Accord et la Convention d'application ont été transférés dans le droit de l'Union, en devenant ainsi partie de l'acquis de l'Union.

Mots clé: accord, Schengen, convention d'application, droit international public, contrôle aux frontierès, Traité d'Amsterdam, acquis de l'Union

Cuvinte cheie: acord, Schengen, convenție de aplicare, drept internațional public, control la frontiere, Tratatul de la Amsterdam, acquis-ul Uniunii

1. Acordul de la Schengen era la origine un act de drept internaţional public, adică o convenţie încheiată între state membre într-un domeniu de competenţă împărțită, care completa dreptul comunitar, mai precis legislația secundară, în materia liberei circulaţii a 
persoanelor. Astfel, deși tratatele permiteau implicit suprimarea controalelor la frontiere ${ }^{1}$, legislația secundară adoptată de Consiliu pentru aplicarea tratatelor permitea doar deplasarea pe baza unui act de identitate, aceasta deoarece unele state membre nu erau de acord cu suprimarea controalelor ${ }^{2}$. Ca atare, statele care au dorit aceasta au recurs la un instrument de drept internațional, Acordul permițând în plus față de dreptul comunitar deplasarea fără controale la frontierele dintre statele părţi. El este expresia Europei cu mai multe viteze, statele părţi devansând restul Comunităţii în îndeplinirea obiectivelor stabilite în materie de liberă circulaţie; el reprezintă o formă de cooperare consolidată, chiar dacă aceasta a fost instaurată expres abia prin Tratatul de la Amsterdam. Semnat în 1985 de Franţa, Germania, Olanda, Belgia şi Luxemburg şi intrat în vigoare în mod diferenţiat - unele prevederi imediat, altele ulterior -, el a fost completat prin Convenţia de aplicare de la Schengen, semnată în 1990 şi, din cauza unor impedimente practice, aplicată abia din 1995, modificată ulterior prin acte de drept unional derivat ${ }^{3}$. Prin Tratatul de la Amsterdam, semnat în 1997 şi intrat în vigoare în 1999, mai precis prin Protocolul care integrează acquis-ul Schengen în cadrul Uniunii Europene, Acordul şi Convenţia ${ }^{4}$ de aplicare au fost transferate în dreptul Uniunii Europene, mai precis în pilonul Justiţie şi Afaceri Interne, devenind parte a acquis-ului unional cu titlul de acte de drept derivat; ca atare, statele membre ale Uniunii care doresc să participe la spațiul Schengen nu mai semnează acorduri de aderare la Acord, ca înainte de integrarea acestuia în dreptul Uniunii, ele participând în virtutea calității lor de membre ale Uniunii în măsura în care, odată cu aderarea la Uniune sau cu semnarea Tratatului de la Amsterdam, nu primesc derogare în acest sens iar Consiliul constată că îndeplinesc condițiile cerute de Acord. La Acord participă actualmente aproape toate statele membre ale Uniunii, mai puţin Marea Britanie, Irlanda, Cipru (primele trei state nu au dorit să fie părţi dar participă totuşi la anumite aspecte, cel de-al treilea a primit derogare în acest sens când a aderat la Uniune), România şi Bulgaria (care nu îndeplinesc toate condiţiile de a participa); Danemarca, deși semnatară, participă doar de la caz la caz la diferite măsuri adoptate; de asemenea, prin intermediul unor convenţii distincte încheiate între ele şi statele Schengen membre ale Uniunii convenții înlocuite ulterior cu acorduri de asociere cu Uniunea -, respectiv prin intermediul unor acorduri de asociere cu Uniunea, sunt părţi la Acord şi Convenţie şi state terţe cum ar fi Islanda, Norvegia, Lichtenstein şi Elveţia.

Acordul are drept câmp material de aplicare suprimarea controalelor la frontierele interne, în scopul facilitării liberei circulaţii mai ales pentru resortisanţii unionali, o politică comună sau cel puţin o armonizare în materie de vize, sejur, control al imigraţiei - aspecte care îi vizează pe cetăţenii statelor terţe -, armonizarea reglementărilor naţionale referitoare la droguri, la arme şi materii explozibile, cooperare judiciară şi poliţienească drept corolar al celor menţionate. Pe bună dreptate s-a considerat că Acordul este un precursor sub anumite aspecte ale liberei circulaţii, el fiind încheiat înaintea Actului Unic European din 1985 care îşi propunea acelaşi obiectiv - un spaţiu fără frontiere interne ${ }^{5}$; de aceea el a prezentat de la început interes şi pentru celelalte state comunitare, care nu erau încă părţi. Odată cu Tratatul asupra Uniunii Europene, semnat în 1992 şi intrat în vigoare în 1993, şi crearea pilonului Justiţie şi Afaceri Interne s-a născut o suprapunere între obiectul acestuia din 
urmă şi cel al Acordului, justificată atunci de faptul că la Acord nu erau părţi toate statele membre şi Acordul nu făcea parte din dreptul Uniunii; această suprapunere a devenit însă ilogică, anormală, odată cu Tratatul de la Amsterdam; mai mult chiar, materiile corespunzătoare aparţinând până atunci pilonului Justiţie şi Afaceri Interne, cu excepţia cooperării judiciare şi poliţieneşti, au fost transferate în Tratatul de instituire a Comunităţii Europene; practic, aceleaşi materii au ajuns să facă atât obiectul Comunităţii Europene cât şi al Acordului Schengen parte a pilonului III, după cum actualmente ele, sub denumirea de spaţiu de libertate, securitate şi justiţie, fac obiectul atât al Tratatului asupra funcţionării Uniunii Europene cât şi al Acordului Schengen! Aceasta chiar dacă, conform Protocolului menționat, Consiliul a stabilit pentru fiecare prevedere din Acord baza juridică din tratat (la ora aceea Tratatul de instituire a Comunității Europene).

Din punctul de vedere al câmpului personal de aplicare Acordul se plasează parţial într-o perspectivă unională, urmărind liberalizarea circulaţiei pentru toţi cetăţenii U.E. şi nu numai pentru cei ai statelor părţi; pe de altă parte îi asimilează totuşi străinilor pe cetăţenii statelor asociate U.E. şi pe membrii de familie - cetăţeni ai statelor terţe - ai cetăţenilor Uniunii, deşi toţi aceştia beneficiază de prevederile dreptului unional privind libera circulaţie; de asemenea, îi asimilează cetăţenilor U.E. pe cetăţenii unor state terţe care participă la spațiul Schengen - Islanda, Norvegia, Liechtenstein, Elveţia -, precum şi pe cetăţenii unor state terţe aflate în uniune vamală cu state ale U.E. - Andorra, Monaco, San Marino, Vatican. Această distincţie nu prezintă însă relevanţă pentru aplicarea dispoziţiilor referitoare la suprimarea controalelor la frontiere, aşa cum vom vedea, ci numai pentru aplicarea celorlalte tipuri de dispoziţii.

Din punctul de vedere al conţinutului său Acordul cuprinde patru categorii de prevederi. Acestea sunt:

a) Suprimarea controalelor la frontierele interne (art. 1-16 și 23-24 din Acord, art. 2-4 din Convenție)

În ceea ce priveşte transportul rutier cu vehicule de turism Acordul s-a aplicat imediat după intrarea lui în vigoare, iar pentru celelalte tipuri de transport el s-a aplicat în etape, inclusiv prin intermediul Convenţiei de aplicare. Aceasta deoarece liberalizarea circulaţiei trebuia corelată cu un control sporit la frontierele externe şi în interiorul teritoriilor statelor. Altfel spus, libera circulaţie nu trebuia să însemne permisivitate şi insecuritate ${ }^{6}$. Obiectul acestor dispoziţii nu îl constituie numai persoanele, ci şi mărfurile şi bunurile de uz personal. Suprimarea controalelor înseamnă de fapt desfiinţarea posturilor de frontieră, fie ele terestre, aeriene sau maritime. Oricare stat poate restabili în mod excepţional şi limitat aceste controale, din motive de ordine publică sau securitate naţională, după consultarea prealabilă sau, în caz de urgenţă, după informarea ulterioară a celorlalte state părţi (art. 2 par. 2 din Convenție). Trecerea frontierelor interne se face deci prin orice loc şi oricând (art.2 din Convenție); trecerea frontierelor externe se face prin punctele desemnate de statul căruia îi aparţine respectiva parte de frontieră şi la orele stabilite de el (art.3 din Convenție), cu excepţia relativă a micului trafic de frontieră ${ }^{7}$ şi a traficului maritim constând în navigaţia de plăcere şi în pescuitul de coastă. 
Beneficiarii acestor dispoziţii sunt toate persoanele care intră pe teritoriul statelor Schengen, indiferent că au cetăţenia Uniunii sau a unui stat terţ.

Teritoriile la care se aplică Acordul sunt teritoriile europene ale statelor părţi (deci excluzând Departamentele şi Teritoriile franceze de peste mări şi dependenţele olandeze în aceeaşi situaţie), precum şi teritoriile Islandei, Norvegiei, Elveţiei şi Liechtensteinului. Rezultă deci că teritoriul Schengen este dintr-un punct de vedere mai restrâns decât al Uniunii, dar din altul este mai extins.

b) Dreptul de azil (art. 28-38 din Convenție)

În ceea ce priveşte dreptul de azil, drept fundamental al oricărui străin persecutat din motive rasiale, etnice, religioase, politice sau sociale, Acordul se inspiră din reglementările internaţionale, adică din Convenţia de la Geneva din 1958 referitoare la statutul refugiaţilor şi prin Protocolul de la New-York din 1967 care o modifică. De ce este reglementat dreptul de azil în legătură cu controlul imigraţiei? Deoarece, în viziunea statelor părţi, el poate fi utilizat abuziv de către persoane care doresc să-şi părăsească ţara din motive economice, devenind astfel un risc de imigrare ilegală̊. De aceea se distinge, ca şi în documentele internaţionale, între străinul imigrant şi cel care caută azil. Acordul instaurează o procedură de examinare a cererilor de azil care să evite depunerea, simultană sau succesivă, de cereri în două sau mai multe state membre: în principiu un singur stat Schengen este competent să examineze o cerere, pe baza unor criterii clar stabilite, rezultatul impunându-se tuturor celorlalte state (art. 29 par. 3 din Convenție). Prin excepţie, în caz de acceptare a unei cereri de azil, unul sau mai multe din celelalte state părţi îi pot totuşi refuza persoanei accesul pe teritoriul lor, dacă o consideră indezirabilă din mai multe motive; de asemenea, în caz de respingere a unei cereri de către statul competent, precum şi în caz de depunere a cererii la alt stat decât cel competent, unul sau mai multe din celelalte state, respectiv statul la care cererea a fost depusă, o pot totuşi examina şi admite (art. 29 par. 4). Mai există, de asemenea, și alte situații în care criteriile de competență nu operează la modul rigid, absolut: când un stat necompetent, pe teritoriul căruia se află solicitantul de azil, nu cere statului competent, în termen de 6 luni, să-și asume tratamentul cererii, ceea ce face ca el să devină competent (art. 31 par. 3 din Convenție); când un stat necompetent, pe teritoriul căruia se află solicitantul de azil, i-a eliberat acestuia un titlu de ședere cu validitate de 1 an sau superioară unui an, ceea ce face ca el să devină competent (art. 33 par. 2 din Convenție); pentru motive umanitare sau culturale, statul competent poate cere altui stat membru examinarea cererii de azil, cu consimţământul persoanei în discuţie (art. 36 din Convenție). De menționat că competența unui stat se extinde și asupra unor membri de familie ai solicitantului, dacă acesta a primit statutul de refugiat și drept de ședere: soțul, copilul celibatar sub 18 ani - dacă solicitantul are 18 ani -, părintele - dacă solicitantul e un copil celibatar sub 18 ani (art. 35 din Convenție). Statul competent este ținut să-I preia pe teritoriul său pe solicitantul de azil aflat ilegal pe teritoriul altui stat Schengen (art. 33 par. 1 din Convenție), exceptând cazul prevăzut de art. 33 par. 2 menționat mai sus. De asemenea, statul competent care a respins o cerere de azil este obligat să-I preia pe solicitantul care s-a deplasat ilegal pe teritoriul altui stat Schengen, 
exceptând cazul în care a luat măsurile care se impuneau pentru a asigura îndepărtarea solicitantului de spațiul Schengen (art. 34 din Convenție).

Au fost fixate următoarele criterii de stabilire a statului competent (art.30 par.1 din Convenție):

- statul care a eliberat viza sau, în lipsa vizei, permisul de şedere; dacă sunt mai multe astfel de state, cel care a eliberat documentul cu scadenţa cea mai îndepărtată; de menţionat că, chiar dacă persoana a părăsit teritoriul statului care a eliberat viza sau permisul de şedere, acest stat rămâne competent atâta timp cât documentul respectiv nu a expirat încă; de asemenea, chiar dacă documentul respectiv a expirat, statul competent rămâne tot cel care l-a eliberat atâta timp cât persoana este încă pe teritoriul său

- în lipsa necesităţii vizei şi a permisului de şedere, statul pe teritoriul căruia persoana a intrat prima dată, indiferent că intrarea a avut loc legal sau nu; dacă, în lipsa unei liste comune, dispensa de viză operează numai din partea unor state Schengen, statul competent e cel sau unul din cele care nu pretind viză/permis de şedere, sub rezerva punctelor anterioare

- dacă, în caz de intrare ilegală, nu se pot cunoaşte locul şi data intrării, statul pe teritoriul căruia a fost semnalată prima dată prezenţa persoanei (aspect ce se poate proba prin orice mijloc)

- dacă nu se poate determina statul competent pe baza criteriilor de mai sus, statul căruia îi este prezentată cererea de azil

c) Politica de vize, intrare și ședere (art. 17-20 din Acord, art. 5-18 din Convenție)

Liberalizarea circulaţiei prin suprimarea controalelor la frontierele interne a făcut necesară o armonizare a legislaţiei statelor părţi privind admiterea pe teritoriu, controlul efectuat la admitere şi chiar statutul străinilor în general, aceasta pentru ca potenţialii imigranţi să nu se folosească de legislaţia cea mai permisivă pentru a intra pe teritoriul statului respectiv, ştiind că apoi vor circula liber şi în celelalte state părţi.

Dispoziţiile privind politica vizelor au ca obiect numai vizele de scurtă ședere - de maximum 3 luni dintr-o perioadă de 6 luni de la prima intrare sau de la intrarea anterioară - şi vizele de tranzit - de maximum 5 zile -, în acest ultim caz indiferent de tipul vizei de ședere. Ele prevăd recunoaşterea reciprocă a vizelor (art. 10 par. 2 și art. 19 par. 2 din Convenție) până la instaurarea unei vize comune (art. 10 par. 1 din Convenție), o viză eliberată de un stat fiind valabilă şi pentru celelalte în măsura în care este eliberată în condiţiile şi după criteriile stabilite conform Acordului, elaborarea unei liste comune a statelor terţe ai căror cetăţeni au nevoie de vize (art. 9 din Convenție) și instaurarea unei vize-tip (vigneta). Dacă persoana solicitantă nu îndeplinește toate condițiile prevăzute pentru eliberarea unei vize comune (a se vedea mai jos), din motive umanitare, de interes naţional sau pentru îndeplinirea unor obligaţii internaţionale un stat membru îi va putea totuși acorda viza dar valabilitatea acesteia va fi limitată la teritoriul său, celelalte state trebuind înștiințate (art. 10 par. 3 și art. 16 din Convenție); la fel și dacă persoanei care nu îndeplinește toate condițiile i se eliberează de către un stat membru un titlu de ședere 
(art. 25 din Convenție). Competenţa pentru eliberarea vizei de ședere aparţine statului care constituie destinaţia principală sau, în caz că aceasta nu poate fi determinată, statul în care persoana intră prima dată (art. 12 par. 2 din Convenție). Pentru vizele de tranzit este competent, evident, statul prin care are loc tranzitul. În lipsa necesităţii vizei persoana are dreptul la liberă circulaţie pe teritoriul celorlalte state tot pe o durată de 3 luni dintr-o perioadă de 6 luni (art. 20 par. 1); de asemenea, posesia unui permis de şedere valabil/a unei autorizații provizorii de ședere valabilă eliberate de un stat membru îi dă dreptul la liberă circulaţie pe teritoriul celorlalte state membre pe o durată de 3 luni dintro perioadă de 6 luni, indiferent de perioada de valabilitate a permisului/autorizației (art. 21 din Convenție); în mod excepţional sau în aplicarea unui acord internaţional încheiat anterior, şederea poate fi prelungită pentru mai mult de 3 luni de către orice stat membru (art. 20 par.2). Condițiile de formă pe baza cărora se eliberează viza de ședere sau, dacă viza nu este necesară, care condiţionează accesul pe teritoriul unui stat şi libera circulaţie pe teritoriul celorlalte state, sunt (art. 5 din Convenție):

- posesia unui document de călătorie (paşaport) valabil pentru toate statele Schengen; în caz că documentul nu este valabil decât pentru unele state, viza sau accesul pe teritoriu vor fi limitate la acestea

- prezentarea, dacă este cazul, de documente care să justifice scopul şi condiţiile şederii

- dispunerea de mijloace de trai suficiente, atât pentru durata şederii cât şi pentru întoarcere sau pentru tranzitul printr-un stat terţ, sau prezentarea de garanţii că aceste mijloace pot fi legal obţinute

- nefigurarea în Sistemul Informatizat Schengen (S.I.S.) ca persoană indezirabilă

- neconsiderarea ca persoană care pune în pericol ordinea publică, securitatea naţională sau relaţiile internaţionale ale unuia dintre statele părţi

Pentru vizele de tranzit condiţiile sunt aceleaşi, mai puţin a doua şi a treia din cele menţionate.

Dacă condiţiile menţionate nu (mai) sunt îndeplinite, persoanei nu i se poate permite intrarea pe teritoriul Uniunii sau pe teritoriul celorlalte state membre, respectiv trebuie să părăsească teritoriul Uniunii (art. 23 par. 1 din Convenție); prin excepţie de la această ultimă obligaţie, dacă persoana dispune de un titlu de şedere (permis sau autorizație provizorie) eliberat de un alt stat membru decât cel pe teritoriul căruia se află, ea poate intra pe teritoriul acelui stat membru (art. 23 par. 2 din Convenție); tot în mod excepţional, din motive umanitare, de interes naţional sau pentru îndeplinirea unor obligaţii internaţionale, statul la frontierele căruia se prezintă persoana îi poate permite acesteia intrarea pe teritoriu dar accesul va fi limitat la teritoriul său, celelalte state trebuind să fie înştiinţate (art. 5 din Convenție).

Alte aspecte urmează a fi stabilite de Consiliu.

În ceea ce priveşte lista comună, ea a fost stabilită prin Regulamentul 539/2001 al Parlamentului și al Consiliului ${ }^{9}$, modificat de Regulamentul 1932/2006 menționat anterior; statele sunt libere să ceară viză şi cetăţenilor altor state decât cele aflate pe listă (cu obligaţia de a comunica Comisiei şi celorlalte state membre acele state terţe), după cum, în cazuri particulare şi în baza cutumelor sau a normelor scrise de drept internaţional, pot 
acorda scutiri cetăţenilor unor state din cele aflate pe listă, în afara scutirilor stabilite de regulamentul însuşi.

Controlul la frontierele externe se face în condiţiile stabilite prin Acord (art.6-8 din Convenție), tocmai pentru că, admiţând un străin pe teritoriul său, un stat îşi asumă răspunderea pentru toate celelalte state părţi; controlul asupra străinilor trebuie să fie complet şi aprofundat în comparaţie cu cel exercitat asupra cetăţenilor Uniunii. De asemenea, din aceleaşi motive, controlul efectuat în cursul şederii în interiorul statelor se supune unor condiţii minimale stabilite tot prin Acord (cum ar fi obligaţia străinilor de a se declara la autorităţile competente, obligaţia lor de a se înscrie în fişele instituţiilor de cazare etc.; art. 22 din Convenție).

d) Cooperarea poliţienească şi judiciară în materie penală (art. 39-91 din Convenție) Asupra acestui aspect nu vom insista, menţionăm doar că el este un mijloc de a încadra eficace libera circulaţie astfel acordată, fără de care aceasta ar deveni poarta unui flux migratoriu. în cadrul cooperării poliţieneşti a fost creat S.I.S. (a se vedea mai jos); în plus, fiecare stat parte este obligat să ofere informaţii necesare celorlalte state părţi şi să acţioneze atunci când i se cere; în lipsa unei asemenea acţiuni statul reclamant are dreptul de a acţiona el pe teritoriul celuilalt, prevederi inedite pentru cooperarea poliţienească şi pentru suveranitatea naţională ${ }^{10}$. Astfel, poliţia unui stat poate continua, pe teritoriul altui stat, supravegherea (observarea) în anumite condiţii ${ }^{11}$ a unei persoane urmărite judiciar pentru anumite fapte care pot da naștere la extrădare ${ }^{12}$ sau a unei persoane despre care există motive serioase să se creadă că poate conduce la identificarea sau localizarea celei care e urmărită judiciar (art. 40 din Convenție); poate continua, pe teritoriul altui stat, la urmărirea în anumite condiţii $^{13}$ a unei persoane aflate în flagrant sau în evadare, pentru anumite fapte ${ }^{14}$ şi pentru faptele care pot da naştere la extrădare (art. 41 din Convenție), şi are dreptul de a o interpela în anumite condiţiii ${ }^{15}$ (art. 41 par. 2 b)din Convenție ). Poliţiile statelor părţi îşi acordă reciproc asistenţă şi fac schimb de informaţii.

Cooperarea judiciară penală constă în simplificarea procedurilor de transmitere a documentelor (art. 52 și 53 din Convenție), în cereri de comisie rogatorie în scop de percheziţie şi de ridicare de obiecte şi/sau înscrisuri (art. 51 din Convenție), în aplicarea principiului non bis in idem (cu condiţia ca persoana să fi executat pedeapsa, să fie în curs de executare a ei sau executarea să nu mai fie posibilă conform legii statului de condamnare; art. 54 din Convenție) ${ }^{16}$, în simplificarea procedurilor de extrădare (art. 59-66 din Convenție) ${ }^{17}$, în transmiterea hotărârilor penale de condamnare în vederea executării lor în alt stat (de exemplu în cazul în care persoana condamnată într-un stat se refugiază în statul de cetăţenie iar acesta, din motive constituţionale, nu-I poate extrăda ${ }^{18}$; art. 67-69 din Convenție).

\section{Sistemul Informatizat Schengen (S.I.S.; art. 92-120 din Convenție)}

Acesta este un sistem de informaţii comun, în care statele membre Schengen semnalează persoane sau obiecte şi cu ajutorul căruia ele dispun de aceste semnalări în scopul 
efectuării controalelor la frontierele externe sau în interior sau în scopul eliberării de vize şi de titluri de şedere. Fiecare stat Schengen creează şi întreţine partea care îi revine din acest sistem informatizat, la frontierele sale externe cu state nemembre. Protecţia datelor personale cu ocazia tratamentului lor trebuie să fie asigurată conform reglementărilor naţionale şi internaţionale, ceea ce implică şi un control din partea unei autorităţi independente.

\section{Comitetul executiv (art. 131-133 din Convenție)}

Acesta era organul creat de Convenţia de aplicare pentru a veghea la buna aplicare a ei şi a Acordului. El se compunea din câte un ministru pentru fiecare stat membru şi statua în unanimitate. În urma integrării Acordului şi a Convenţiei sale de aplicare în dreptul Uniunii, Comitetul a fost înlocuit de Consiliul Uniunii.

\section{Dispoziţii finale (art. 134-142 din Convenție)}

Se prevede că Convenţia (şi, implicit, şi Acordul) nu este aplicabilă decât în măsura în care este compatibilă cu dreptul comunitar (actualmente unional).

Statele membre Schengen se angajează să nu încheie cu state terţe acorduri având ca obiect reducerea sau suprimarea controalelor la frontiere, fără acordul celorlalte state membre şi, evident, sub rezerva dreptului pe care îl au statele membre ale Comunităţii (actualmente ale Uniunii) de a încheia acorduri comune cu terţii şi exceptând micul trafic de frontieră.

2. În ceea ce priveşte situaţia României cu privire la Acordul Schengen, în Acordul de aderare la Uniune se prevede că participarea României la spaţiul Schengen nu va avea loc decât în urma unei decizii a Consiliului prin care acesta constată că sunt îndeplinite toate condiţiile cerute. Fără o asemenea clauză, participarea României ar fi avut loc de drept, având în vedere apartenenţa Acordului Schengen la acquis-ul unional. Se preconiza ca aderarea să aibă loc în martie 2011.

Prima decizie a Consiliului în acest sens a fost emisă în iunie $2010^{19}$ şi vizează aplicarea aspectelor tehnice ale Acordului (S.I.S.) în România, constatând că sunt îndeplinite condiţiile de natură tehnică. Legea 141/12.07.2010 ${ }^{20}$ vizează înfiinţarea, organizarea şi funcţionarea Sistemului Informatic Naţional de Semnalări şi participarea României la sistemul de informaţii Schengen. De atunci nu a mai fost adoptată nicio decizie formală a Consiliului privind aderarea sau respingerea aderării României la spaţiul Schengen ${ }^{21}$, refuzul opus fiind exprimat doar neoficial, politic. Cu ocazia reuniunii Consiliului din decembrie 2013, constatându-se din negocieri imposibilitatea adoptării unei decizii de aderare a României, aceasta - împreună cu Bulgaria - a dat o declaraţie prin care precizează că va solicita reluarea discuţiilor în Consiliu numai când premisele politice vor fi favorabile unui rezultat pozitiv. De atunci nu există nicio agendă clară de punere la vot a aderării României la spaţiul Schengen. Oricum, aderarea se va decide pe baza unui raport de evaluare, raport elaborat la rândul lui în urma unor vizite de evaluare pe categorii de aspecte. 
Refuzul unor state (Germania, Finlanda, Austria, Olanda) se bazează pe lipsa reformelor complete în domeniul justiţiei şi pe corupţia - implicit şi a personalului de frontieră -, aspecte care ar împiedica un control eficient la graniţele externe ale României şi, deci, ale spaţiului Schengen. Totuşi, aşa cum se recunoaşte dealtfel de către oficiali ai Uniunii, aceste criterii nu figurează printre cele impuse de Acord, România îndeplinindu-le pe acestea din urmă. Din punct de vedere juridic se poate preconiza o acţiune a României în faţa justiţiei unionale, fie una în carenţă - dacă Consiliul nu emite nicio decizie -, fie una în anulare - dacă Consiliul emite o decizie de respingere -, deoarece "aderarea", adică participarea la o politică a Uniunii este un drept şi o obligaţie (în lipsa unei derogări) a fiecărui stat membru în măsura în care sunt îndeplinite condiţiile prevăzute de dreptul Uniunii.

${ }^{*}$ Conferenţiar, Facultatea de Studii Europene, UBB Cluj-Napoca; crmnlazar@yahoo.fr.

${ }^{1}$ Astfel, art. 48 par. 3 din Tratatul de instituire a Comunității Europene, referitor la libera circulație lucrătorilor salariați, prevede că libera circulație comportă, printre altele, dreptul de a se deplasa liber (n.n.) pe teritoriul statelor membre; nefăcându-se nicio precizare cu privire la ceea ce înseamnă liber, interpretarea corectă este că acest termen permite deplasarea fără controale la frontiere. Art. 52-58 referitoare la libertatea de stabilire (libera circulație a lucrătorilor independenți) și 59-66 referitoare la libera circulație a serviciilor nu mai prevăd nimic despre deplasare, ceea ce înseamnă că trebuie să ne raportăm tot la art. 48 par. 3 . Aceste prevederi nu au fost modificate prin tratatele ulterioare.

2 Suprimarea controalelor trebuia corelată cu politici comune în materie de liberă circulație a cetățenilor statelor nemembre, ca să nu aibă efecte nedorite asupra statelor; or, până la Tratatul asupra Uniunii Europene, care în pilonul său III introducea aceste politici, cele mai multe state membre nu erau pregătite pentru așa ceva.

${ }^{3}$ Cum ar fi, de exemplu, Regulamentul 1931/2006 al Parlamentului și al Consiliului - publicat în Jurnalul Oficial L 405/30.12.2006 -, Regulamentul 1342/2011 al Parlamentului și Consiliului - publicat în Jurnalul Oficial L 347/30.12.2011.

${ }^{4}$ Precizăm că, deşi pentru simplificarea exprimării vom folosi doar termenul "Acord", în realitate ne vom referi şi la Convenţia de aplicare.

${ }^{5}$ V. Hreblay, „Les accords de Schengen”, Ed. Bruylant, Bruxelles, 1998, p.16-17.

${ }^{6}$ idem, p.20.

${ }^{7}$ Acesta e reglementat de Regulamentul 1931/2006 - citat - și Regulamentul 1932/2006 - publicat în Jurnalul Oficial L 405/30.12.2006 -, ambele ale Parlamentului și Consiliului; prin mic trafic de frontieră se înțelege deplasarea pentru motive economice, sociale, culturale sau familiale, pentru o durată de maxim 3 luni neîntrerupte, într-o zonă de maxim $30 \mathrm{~km}$ de la graniță - numită zonă de frontieră - în principiu, a unei persoane care locuiește de cel puțin 1 an în zona de frontieră a statului terț vecin cu statul membru în discuție (persoană numită frontalier); excepția e relativă deoarece statele pot - dar nu sunt obligate -, ținând cont de circumstanțele locale și în mod excepțional, dacă există o nevoie particulară, să permită pentru frontalieri trecerea prin alte puncte decât cele stabilite, după cum pot facilita trecerea lor fie creând puncte de control anume pentru frontalieri, fie creând culoare speciale la punctele obișnuite de control; deplasarea se face pe baza unui permis special și, eventual a unui document de călătorie (dacă acesta e prevăzut în acorduri bilaterale între state membre și state terțe vecine), dar fără viză, chiar dacă statul de cetățenie al frontalierului figurează pe lista comună a statelor ai căror cetățeni au nevoie de viză. 
8 idem, p.7.

9 Publicat în Jurnalul Oficial L 81/21.03.2001.

10 idem, p.149-150.

${ }^{11}$ Existenţa unei autorizaţii date de statul pe teritoriul căruia supravegherea are loc, pe baza unei cereri prealabile de întrajutorare judiciară, exceptând cazurile de urgenţă; în această ultimă situaţie statul pe teritoriul căruia supravegherea are loc trebuie înştiinţat şi trebuie să i se ceară între timp autorizarea menţionată; agenţii supraveghetori nu au dreptul să intre în locurile neaccesibile publicului, nu au dreptul să efectueze interpelări (cu excepția arătată mai jos) şi arestări; la cererea statului pe teritoriul căruia are loc supravegherea, aceasta i se va încredinţa lui; trebuie să dea curs oricărei injoncţiuni din partea statului respectiv.

12 Acestea sunt: omorul, incendiul, infracțiunile grave de natură sexuală, falsificarea de mijloace de plată, furtul agravat şi tăinuirea aferentă, şantajul, răpirea şi luarea de ostatici, traficul de persoane, traficul ilicit de stupefiante şi substanţe psihotrope, transportul ilicit de deşeuri toxice şi dăunătoare, infracţiuni la legislaţia în materie de arme şi explozibile, distrugerea prin explozibile, fuga de la locul unui accident care a antrenat moartea sau vătămări corporale grave, înșelăciunea, filierele de imigrație clandestină, spălarea de bani, traficul cu substanțe nucleare și radioactive, participarea la o organizație criminală, terorismul.

${ }^{13}$ Atunci când autorităţile statului pe teritoriul căruia are loc urmărirea nu au putut, din cauza urgenţei, fi înştiinţate la timp, ca să-şi dea autorizarea prealabilă; urmărirea poate avea loc într-o anumită perioadă de timp de la trecerea frontierei şi într-o anumită zonă sau fără limitarea de timp şi spaţiu, în funcţie de declaraţia pe care o face fiecare stat membru; agenţii urmăritori nu au dreptul să intre în locurile neaccesibile publicului; trebuie să dea curs oricărei injoncţiuni din partea statului respectiv; trebuie să poată fi identificaţi cu uşurinţă; urmărirea nu poate avea loc decât pe la frontierele terestre.

${ }^{14}$ Acestea sunt cele menţionate la nota 11.

${ }^{15}$ Atunci când agenţii statului pe teritoriul cărui are loc urmărirea nu pot interveni suficient de rapid şi nici nu au cerut încetarea urmăririi; interpelarea durează până când agenții statului respectiv, informați imediat, pot stabili identitatea persoanei sau pot proceda la arestarea ei.

${ }^{16}$ Un stat membru poate declara că nu va aplica acest principiu în anumite cazuri, stabilite de Acord (art. 55 din Convenție): când fapta care face obiectul condamnării în alt stat a fost comisă parţial pe teritoriul primului; cînd fapta este o infracţiune la siguranţa primului stat; când fapta a fost comisă de un funcţionar al primului stat. Chiar în caz de neaplicare a principiului, statul care urmăreşte a doua oară trebuie să ţină cont de perioadele în care persoana a fost privată de libertate pe teritoriul statului de condamnare, pentru a i le deduce din pedeapsa pe care o va aplica; de asemenea, în măsura în care acest lucru e permis de legislaţia sa, el va trebui să ţină cont şi de alte sanç̧iuni decât cele privative de libertate.

${ }^{17} \mathrm{Cu}$ precizarea că dispoziţiile referitoare la extrădare nu mai sunt valabile între statele membre UE, ele fiind înlocuite de Decizia-cadru 584/2002/JAI a Consiliului referitoare la mandatul european de arestare, publicată în Jurnalul Oficial al Uniunii Europene nr. 190/18.07.2002; extrădarea în general vizează persoanele urmărite pentru a fi judecate şi condamnate sau persoane căutate în vederea executării unei pedepse sau a unei măsuri de siguranţă.

${ }^{18}$ Sub imperiul mandatului european de arestare problema nu se mai pune.

${ }_{19}$ Decizia 365/29.06.2010, publicată în Jurnalul Oficial al Uniunii Europene L 166/1.07.2010.

${ }^{20}$ Publicată în Monitorul Oficial nr. 498/19.07.2010.

${ }^{21}$ Aceasta deşi procedura a fost declanşată, ob̧̧inându-se şi avizul pozitiv al Parlamentului European în iunie 2011; Consiliul a adoptat concluzii cu privire la finalizarea procesului de evaluare a stadiului de pregătire a României, concluzii prin care decide amânarea votului, ca urmare a existenţei opoziţiei unor state. 